Journal of Business and Tourism

Volume 05 Number 01

January-June, 2019

\title{
Impact of Team Identification on Fans' Trust after Negative Incident: Moderating Role of Mass Media
}

\author{
UZMA NOOR \\ Lecturer, Faculty of Management Sciences \\ International Islamic University, Islamabad, Pakistan \\ Uzma.amer@iiui.edu.pk \\ DR. ABDUL QAYYUM \\ Associate Professor, Faculty of Management Sciences \\ Riphah International University, Islamabad, Pakistan \\ DR. SHAMS UR REHMAN \\ Assistant Professor \\ Northern University, Nowshehra
}

\begin{abstract}
Sports marketing being a new and under researched area is highly dependent on mass media treatment. The purpose of this study is twofold: First to examine the impact of team identification on fans trust after the involvement of a player in a negative incident, and second to examine the impact of media (fans' perceived content informativeness, content credibility and source credibility of TV cricket talk shows) on this relationship. Data is collected via convenience sampling from a total of 399 respondents belonging to three universities, local markets, and friends from Islamabad and Rawal Pindi twin cities of Pakistan. Simple and moderated multiple regression analysis reveals that team identification positively affects fans' trust after negative incident. Perceived source credibility, content credibility and informativeness of cricket talk shows on TV (mass media) moderates the relationship of team identification and fans' trust after negative incident in such a way that the relationship becomes stronger regardless the media is positively or negatively highlighting the negative incident. The results of the current research might help sports marketing and media related organizations to understand sports fans' behaviors towards sports organizations in connection of the conflict.
\end{abstract}

Keywords: Sports Marketing, Cricket, Team Identification, Mass Media, Credibility, Informativeness, Trust, Negative Incidents, Social Identity Theory

\section{Introduction}

History of professional sports shows that there are plenty of negative incidents engulfing professional players (AFP, 2006). In sports context, a negative incident may be referred to as player's performance or integrity related negative or unethical behavior. Either on field or off field, it may create problem not only for the player/team and sporting organization but also for sponsors (Lee et al., 2013; Wilson et al., 2008). Negative incidents related with sports players/team have special meaning to sports fans too because fans are emotionally involved with sports teams (Madrigal \& Dalakas, 2008; Tajfel \& 
Turner, 1985). Sports fan's trust on players after any negative incident plays a crucial role in building and maintaining relations with players, coaches, and teams (Lee et al., 2013, Morgan \& Hunt, 1994). If nothing is being done to maintain trust after a negative incident, the negative incident may negatively affect the image of team or players. As over a period of time sports fans develop psychological attachment or connectedness with a favorite player or team leading towards an attitude called team identification. A highly identified fans remain loyal with the team, even after the team loses the match, than moderately or low identified fans (Wann \& Branscombe, 1990b), but team identification's impact on fan's trust after a negative incident needs to be explored. In this whole process communicating with fans through media after negative incidents becomes a critical issue not only to cause further damages and distrust, but to mend the damage too (Lee et al., 2013). Media plays a prominent role to affect the image of any overall sports too (Wilson et al., 2008). The relationship between media and professional sports is interdependent (Bruce \& Tini, 2008). The present study aims at exploring the effect of team identification on fans trust after a negative incident related to the players' on or off field behavior in context of cricket sports specifically in Pakistan. This study will also investigate the moderating effect of sports media (TV talk show) on the relationship of team identification and trust after negative incident.

\subsection{Situation of Cricket Sports in Pakistan}

In Pakistan, cricket is the biggest source of recreation for people. History of cricket goes back to sixteenth century. This game, invented by British as "creckett" in the sixteenth century, was popularized by British Empire in Indo-Pak subcontinent in 1800s (Sudarsan, 2012). Though, it is not the national game of Pakistan but the love for this game among Pakistanis unprecedented. The victory of 1992 cricket World Cup marked the entry of green shirts into the international arena. In the new millennium, cricket went through an overhaul - truncated to twenty overs a side in which result could be achieved in three hours - about as long as a baseball game - perfect for an evening's entertainment (Sudarsan, 2012). In addition to winning the 1992 Cricket World Cup, Pakistan cricket team has won other international cricket events like 2009 ICC World Twenty20, it was runner-up in the 1999 Cricket World Cup and the 2007 ICC World Twenty20. Heavy media coverage of sports events and news not only plays tremendous role in fulfilling the voracious enthusiasm of people for cricket, but also an enormous role in increasing it further (Lee et al. 2013).

On or off field negative incidents about the sports players or teams get much media and fans attentions alike (Fink et al., 2009). Media plays a significant role in either highlighting the negative aspects of the negative incident or presenting it as a mere rumor or highlighting the aspects which may provoke people to consider the accused as innocent and thus maintaining peoples' trust. In the Pakistan cricket spot-fixing scandal of 2010, three players of Pakistani cricket team were accused of accepting bribe to show low performance at certain times during the match against England in London cricket ground. Salman Butt, M. Asif and M. Amir were suspended by the International Cricket Council (ICC) to play for 5 years. This is not the only case caught by media, there is list as shown in Table 1. Examining the extent to which people are willing to trust a team after negative incident related to a player, is a significant research avenue (Lee et al., 
2013). Present study is an effort to explore the impact of media on the relationship of team identification and fans' trust after negative incident of cricket sports in Pakistan.

Table 1: Negative Incidents associated with Pakistan National Cricket Team (Pakistan Cricket Board, 2014)

\begin{tabular}{|c|c|c|c|}
\hline Dates & Player(s) & Incident & Sentence \\
\hline 1993 & $\begin{array}{l}\text { Wasim } \text { Akram, } \\
\text { Waqar Younas, } \\
\text { Aaqib Javed and } \\
\text { Mushtaq Ahmed }\end{array}$ & $\begin{array}{l}\text { They were caught on the beach } \\
\text { smoking Marijuana or Cannabis }\end{array}$ & $\begin{array}{l}\text { Jailed in the Caribbean for } 2 \\
\text { nights }\end{array}$ \\
\hline 2005 & Shoaib Akhtar & $\begin{array}{l}\text { He had shown poor attitude in Test } \\
\text { match series in Australia }\end{array}$ & Sent back home \\
\hline 2005 & Shahid Afraidi & $\begin{array}{l}\text { Deliberately tried to damaging the } \\
\text { pitch with boots in test series against } \\
\text { England }\end{array}$ & $\begin{array}{l}\text { Banned from test match and two } \\
\text { ODIs }\end{array}$ \\
\hline 2006 & Muhammad Asif & $\begin{array}{l}\text { Tested positive for anabolic steroid, } \\
\text { Nandrolone }\end{array}$ & A ban was imposed on him \\
\hline 2006 & Shoaib Akhtar & $\begin{array}{l}\text { Drugs/Steroids usage for } \\
\text { performance enhancing }\end{array}$ & Ban imposed \\
\hline 2007 & Shoaib Akhtar & $\begin{array}{l}\text { Fought with team mate Muhammad } \\
\text { Asif }\end{array}$ & Banned for indefinite period \\
\hline 2007 & Shahid Afraidi & $\begin{array}{l}\text { He was seen on camera thrusting his } \\
\text { bat at a spectator who swore at him }\end{array}$ & Four-game ODI suspension \\
\hline 2008 & Muhammad Asif & $\begin{array}{l}\text { Tested positive for a banned } \\
\text { substance during the Indian Premier } \\
\text { League }\end{array}$ & $\begin{array}{l}\text { Detained in Dubai suspected of } \\
\text { having drugs }\end{array}$ \\
\hline 2010 & Muhammad Asif & He was involved in Spot-fixing & $\begin{array}{l}\text { On } 3^{\text {rd }} \text { November 2011, Asif was } \\
\text { given a one-year prison sentence }\end{array}$ \\
\hline 2010 & Shahid Afraidi & $\begin{array}{l}\text { He was caught on camera for Ball } \\
\text { tempering in } 5^{\text {th }} \text { Commonwealth } \\
\text { Bank ODI series in Australia }\end{array}$ & $\begin{array}{l}\text { Banned from two Twenty } 20 \\
\text { internationals. }\end{array}$ \\
\hline 2010 & Salman Butt & He was involved in Spot fixing & $\begin{array}{l}\text { 10-year ban, of which five years } \\
\text { is a suspended sentence. In } \\
\text { November 2011, jailed for } 30 \\
\text { months }\end{array}$ \\
\hline 2010 & $\begin{array}{l}\text { Mohammad } \\
\text { Aamer }\end{array}$ & He was involved in Spot fixing & $\begin{array}{l}5 \text { year ban. In November } 2011 \text {, } \\
\text { he was convicted and jailed for } 6 \\
\text { months }\end{array}$ \\
\hline 2011 & Shahid Afraidi & $\begin{array}{l}\mathrm{He} \quad \text { had clashes } \\
\text { misunderstanding with PCB }\end{array}$ & $\begin{array}{l}\text { PCB suspended Afridi's central } \\
\text { contract, fined him } 4.5 \text { million } \\
\text { rupees and revoked his NOC. }\end{array}$ \\
\hline 2013 & $\begin{array}{l}\text { Kashif Sadique } \\
\text { (domestic cricket) }\end{array}$ & $\begin{array}{l}\text { He violated Article } 2.1 \text { of the PCB's } \\
\text { Anti-Doping Code }\end{array}$ & Ban of 2 years \\
\hline
\end{tabular}

\section{Literature Review}

\subsection{Team Identification}

Identifying means 'to associate oneself with another person.' Identification is the state of psychologically associating and attaching oneself with the characteristics present in the group members (So et al., 2013). In identifying with some group or a person, one maintains personal identity as well as social identity (Tajfel \& Turner, 1985; Ashforth \& Mael, 1989). Social identity theory (Tajfel \& Turner, 1979) proposes that the groups such as social class, family, or sport team to which individuals belong are important sources of pride and self-esteem. In sports context, identification with a particular sports player/team is referred as team identification. Ashforth and Mael (1989) have defined team 
identification as the spectator's perceived connectedness to a team and the experience of team's failings and achievements as one's own. Previous studies have proved that highly identified fans show in group bias (Dietz-Uhler et al, 2002) in case of negative incident of their favorite player. But in some cases player identification has no significant effect and do not favor or inclined towards balance theory or black sheep effect (Wann et al, 2006). So for our study we chose the notion that due to team identification, fans show positive attitude towards their favorite team even after the involvement of a player from the team in a negative incident. And team identification effect positively and significantly to trust after negative incident.

\section{a. Trust after Negative Incident}

Trust is one of the key factors required for the development of successful relationships and central to all relational exchanges (Morgan and Hunt, 1994). It plays crucial role in the establishing, developing and maintaining of relationships. In the sports context, its importance as a building block of relationships is even greater, since the relationship of fans for players, coaches, and teams is basically based on trust factor (Lee et al., 2013). Sports marketing deals with maintaining relationships with sports consumers through exchange process (Mullin et al., 2000). It has been seen that due to brand identification consumers trust their brand even after negative incident (Mattila, 2001). Brand identification is not only conceptually related with favorable perceived value, but also associated with the concept of brand trust. On one side, it is suggested that trust is the reason to develop identification with certain brand or organization, because consumers want a trustworthy brand through which they may express themselves and increase selfesteem. (Keh \& Xie, 2009). Marketing literature suggests that past experience with the brand is the principal reason of trust development (Delgado-Ballester \& MunueraAlemán, 2001; Delgado-Ballester et al., 2003; Ravald \& Gronroos, 1996), whereas organizational research has given the concept of "identification-based trust," in which instead of past interaction or experience, the trust is due to individuals' identification with the social entity (Kramer, et al., 1996). It suggests that in sports context, peoples' team identification may provide a platform for peoples' trust development. Because of the feeling or sentiments of close attachment (Trail, et al., 2000), fans develop identification with teams (Madrigal \& Dalakas, 2008). It is one of the reasons that negative incidents linked to sports personnel (e.g., player, coach) are perceived differently by fans as compared to other negative incidents, for example, an executive involved in fraudulent transactions (Lee et al., 2013). According to Dietz-Uhler et al. (2002), identification of individual with groups motivates them to have in-group bias, which can be explained by social identity theory (Tajfel \& Turner, 1979). On interpretation of this theory is that fans highly identified with the cricket team evaluate the team favorably, unconditionally and maintain their trust on the cricket team even after a negative incident.

\section{b. Mass Media}

Mean of communication through which a message reaches to a large number of people in a short time is called mass media. It can include television, radio etc (Potter, 2011). Since long credibility of communication has been given special attention. Media credibility refers to the perceived believability of media content "beyond any proof of its contentions" (West, 1994). For effective communication, media credibility is an important requirement along with the characteristics of message and audience (Zhu \& 
$\mathrm{He}, 2002)$. In the context of publics' trust after a negative incident related to cricket team, credibility and informativeness (among the attributes of message content) of TV cricket discussions are the most relevant contents of the message which are sought by the public and can possibility have the most effect on their trust after negative incident towards the team. Therefore in present study we have considered only source credibility, content credibility as well as content informativeness as the value/effect determinants of media content (TV cricket shows).

\section{c. Source Credibility}

Source credibility is defined as communicator's positive characteristics that affect the receiver's acceptance of the message (Ohanian, 1990). Aristotle being first to give the concept of source credibility emphasizes that source credibility must be present at the time when the message is being delivered irrespective of what the source said. Empirical research on source credibility began in $20^{\text {th }}$ century. After the Second World War, many researchers focused on persuasion as US government wanted public to support the war. Due to this reason, academic interest in source credibility increased. The idea of credibility of a source has been advanced in advertising and marketing literature as corporate credibility, advertiser credibility, institutional credibility, or retailer credibility. Goldsmith, et al., (2000) defined corporate credibility as the degree to which consumers, investors and others believe in the organization's trustworthiness and expertise. If we look in the perspective of organizational credibility, the source of a message is not an individual person but is organizational structure which is complex and whose experience and information has already been exposed to public. However researcher found that dimension of organizational credibility are similar to that of source credibility research (Mackenzie \& Lutz, 1989). Therefore dimensions of organizational credibility include expertise, trustworthiness and attractiveness (Ohanian, 1990), although prestige, competitiveness and familiarity have also been identified as dimensions of organizational credibility (Vanden, Bergh, Soley \& Reid, 1981).

\section{d. Content Credibility and Informativeness}

Content informativeness is the attribute that provide helpful, timely and accurate information (Siau \& Shen, 2003). The prime purpose of informativeness is to provide an individual with alternatives necessary to make choices (Rotzoll et al., 1990). It helps in developing the attitude of consumer toward advertized product on media (Gao \& Koufaris, 2006). Several researchers have studied certain value determinants of advertising media which affect consumers' attitude (Koo et al., 2012; Ducoffe, 1996; Ducoffe, 1995) and resulting in behavioral influence (Ajzen, 1991). The information provided through media influence the perception of customers. People need relevant (Milne \& Gordon, 1993) and quick information for the content they are looking for (Kaasinen, 2003). Advertising credibility may be defined as the consumers' perception of truthfulness (Eisend, 2006) and believability of advertising in general (MacKenzie \& Lutz, 1989). Whereas content credibility is defined as the extent to which the message delivered in individual ad/message is perceived as truthful and believable. Credibility of advertisement can be influenced by number of factors such as company's credibility, types of recipients and medium (Goldsmith et al., 2000; Lafferty et al., 2002).

According to Brackett and Carr (2001), credibility and informativeness are the attributes which determine the advertising value and create favorable attitude of people towards 
advertising. Informative and entertaining advertising create value for consumers but advertising value developed through informativeness and entertainment help in developing favourable attitude towards advertising (Ducoffe, 1996, 1995). In the context of public trust after a negative incident related to cricket team, credibility and informativeness (among the factors mentioned above) of TV cricket discussions are the most relevant attributes which are sought by the public and can possibility have the most effect on their trust after negative incident towards the team. Therefore present study is considering credibility and informativeness as the value/effect determinants of media (TV cricket shows). The extensive literature review reveals that no exactly comparable research has examined relationships similar to this. In addition, to the best of my research efforts there is no single questionnaire available which measures the impact of mass media. It has been found out that impact of media, via measuring the impact of source credibility, and credibility and informativeness of the message presented by mass media, on the relationship of peoples' team identification and their trust after a negative incident has not yet been investigated, neither in Pakistan nor elsewhere.

\section{Conceptual Framework and Hypothesis}

Team Identification and Trust after Negative Incident

It is clear from previous work that team identification may stimulate affective responses (e.g. Wann, et al., 2002; Wann \& Branscombe, 1993), psychological responses (e.g. Wann \& Polk, 2007; Wann \& Branscombe, 1993), and behavioral responses (e.g. Janssen \& Huang, 2008; Wann \& Branscombe, 1993). Study findings of Wann, et al., (1994) indicate fans are highly expected to demonstrate positive emotional responses toward their favorite sports teams and the extent of affective reactions is larger in fans that identify themselves highly with a team than in fans with lower identification with the team. Literature also suggests that highly identified fans are more likely to have positive attitudes and behavior toward the team (Gwinner \& Swanson, 2003; Roccas \& Brewer, 2002; Newcomb, 1961; Heider, 1958). These views suggest that team identification is likely to have a direct positive impact on fan's trust after a negative incident of the player. Also, the results of our pilot study confirmed that team identification will affect trust after negative incident in the positive direction. Therefore it is hypothesized that "Team identification is positively and significantly related to fans' trust on their favorite team after player's involvement in a negative incident" $\mathbf{H}_{\mathbf{1}}$.

Moderating Role of Mass Media

According to cultivation theory, mass media has influence on human attitudes and personality (Kwak et al., 2002; Garbner et al., 1978). Media focus can be an influencing factor on how people perceive negative incidents (Wilson et al., 2008). For example, the effect on team identification of fans in case of a player involved in on or off field negative incidents. Mass media is a factor that influences the trust relationship between consumers and brands at the time of brand crises (Yannopoulou et al, 2011). A precursor of trust is communication which can be defined as formal or informal sharing of timely and meaningful information between two parties (Anderson \& Narus, 1990). It suggests that in sports context, the relationship between fans' team identification and their trust on team after a negative incident may be more complex and that media portrayal of the negative incident can interact with fans' team identification to affect their trust after a negative incident. The impact of a message depicted by the mass media depends mainly 
upon the source credibility, content credibility and the medium credibility through which the message is communicated (Verma, 2014; Kiousis, 2001; Hovland et al., 1953). Consumers' trust in advertising media and its credibility are different but associated constructs (Soh et al., 2007). Therefore, discussing credibility without referring to trust is difficult (Verma, 2014).

Modifications in the source characteristics influence peoples' willingness to alter their attitudes towards topic of the message (Kiousis, 2001). According to the theory of attribution, people will disregard the arguments in a message if source credibility is low (Eagly \& Chaiken 1975). Thus the result of a message or information or claims will be perceived as less useful if made by a low-credibility source in a program on media. Ultimately it fails to influence peoples' attitudes towards the topic. (Luo, et al., 2013; Grewal, et al., 1994; Kiousis, 2001). Similarly when source credibility is high, the information or claims made by the source will have an impact of changing peoples' attitudes in the direction desired by the source. These notions suggest that source credibility of the message depicted by the sports media (TV cricket discussion shows) can interact with fans' team identification to affect their trust on the team after a negative incident.

Communication can be described as glue that holds different parties together (Morgan \& Hunt, 1944). Communication which is timely, reliable and relevant results in greater trust (Moorman et al., 1993; Anderson \& Narus, 1990; Morgan \& Hunt, 1944). It fosters trust by solving the disputes and aligning expectations and perceptions (Etgar, 1979). Similarly, credibility and informativeness of the message content are the attributes which provide believable and timely information and that have direct effect on advertising value and attitude towards advertising (Brackett \& carr, 2001). So both attributes determine the effect of the message communicated by media effecting peoples' attitudes toward the topic. It suggests that content credibility and informativeness of the message depicted by sports media (TV cricket discussion shows) can also interact with fans' team identification to affect their trust after a negative incident. In light of the above discussion, we hypothesize the following:

Scenario 1- Views by media are in favor of accused

$\mathbf{H}_{2 \mathbf{a}}$ Informativeness of message content communicated by TV cricket talk shows (mass media) moderates the relationship of team identification and fans' trust after negative incident in such a way that the relationship becomes stronger if perceived content informativeness is present.

$\mathbf{H}_{2 b}$ Credibility of message content communicated by TV cricket discussion shows (mass media) moderates the relationship of team identification and fans' trust after negative incident in such a way that the relationship becomes stronger if perceived content credibility is present.

$\mathbf{H}_{2 \mathrm{c}}$. Credibility of spokespersons on TV cricket discussion shows (mass media) moderates the relationship of team identification and fans' trust after negative incident in such a way that the relationship becomes stronger if perceived source credibility is present.

Scenario 2- Views by media are against the accused

$\mathbf{H}_{3 \mathrm{a}}$. Informativeness of message content communicated by TV cricket talk shows (mass media) will moderate the relationship of team identification and fans' trust after negative 
incident in such a way that the relationship will be weaker if perceived content informativeness is present.

$\mathbf{H}_{3 \mathbf{b}}$. Credibility of message content communicated by TV cricket talk shows (mass media) will moderate the relationship of team identification and fans' trust after negative incident in such a way that relationship will be weaker if perceived content credibility is present.

$\mathbf{H}_{3 \mathrm{c}}$. Credibility of spokespersons on TV cricket talk shows (mass media) will moderate the relationship of team identification and fans' trust after negative incident in such a way that the relationship will be weaker if perceived source credibility is present.

Current study aims at examining the relationship between team identification and trust after negative incident, along with considering the moderating impact of mass media on this relationship. Figure 1 illustrates the proposed research model for this study. This figure shows that team identification is independent variable and trust after negative incident is dependent variable. Media impact is the moderating variable. Source credibility, and credibility and Informativeness of the message content are the attributes which determine the impact of message presented by media. Therefore their moderating impact would be examined on the relationship of team identification and fans' trust after negative incident.

Figure 1: Conceptual Framework

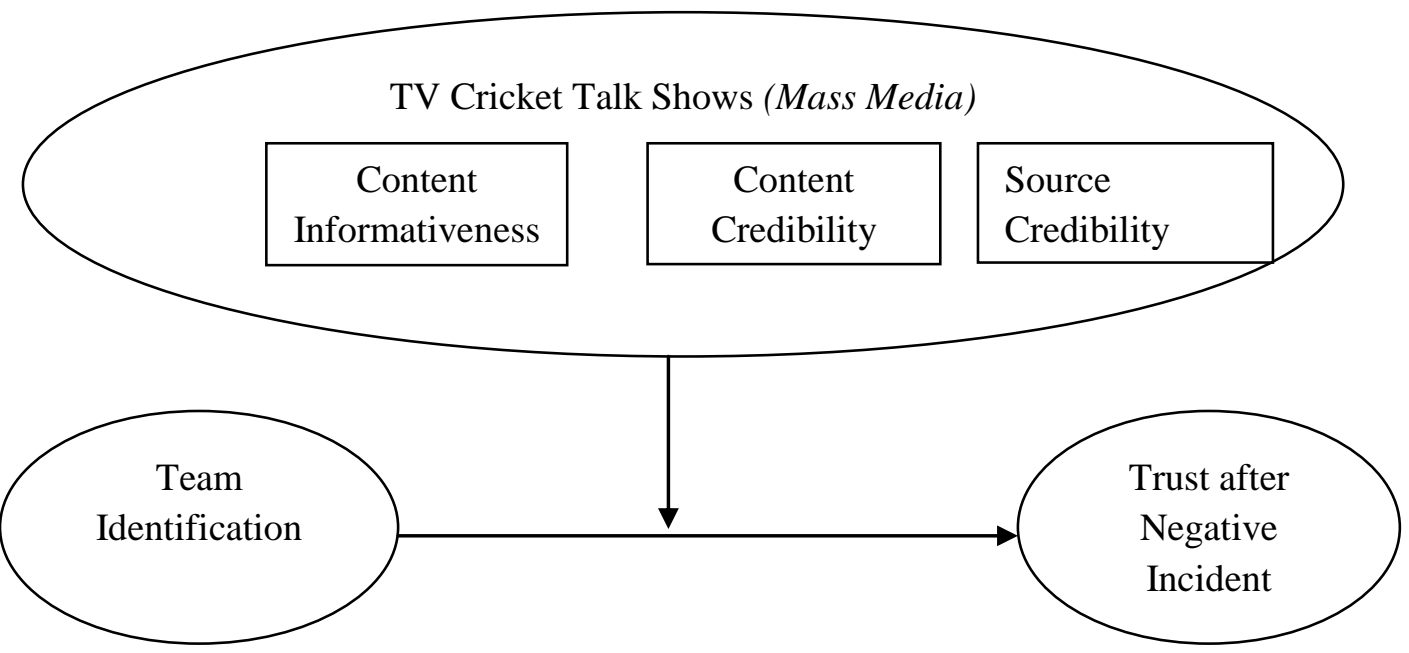

Although the relationship of brand identification and brand trust has been studied by researchers (So et al., 2013), to the best of our knowledge, the relationship of team identification and its effect on fans' trust after negative incident in sports context has not been explored yet. Exploring the moderating role of mass media quantitatively is also a contribution of this study and the way we will measure the moderating role of mass media is a novelty of present study.

\section{Methodology}

The current study is quantitative and experimental in nature. Data is collected through structured questionnaires and telling scenarios about TV talk shows. The measures to be used in the current study have been chosen for two reasons. First they have consistently 
strong reliabilities across a number of prior studies (for instance, Informativeness scale has been earlier used by Ducoffe (1995); content Credibility scale has also been used by MacKenzie and Lutz (1989) and Moore and Rodger (2005); source credibility scale has also been used by Ohanian (1990); Brand Trust scale has been earlier used by Matzler, et al., (2011) and Delgado-Ballester (2004); Team Identification scale has also been used by Wann and Branscomb (1993); Lee and Ferreira (2011); and Wann, et al., (2001). Second the measures tap the attitudes which are relevant for the current study. As the population increase, the sample size increases at the diminishing rate and becomes constant at slightly more than 380 cases Krejcie and Morgan (1970). This study is conducted in Rawalpindi and Islamabad twin cities of Pakistan where population relevant for current study is 4.7 million approximately therefore estimated sample size is 399 .

As cricket fans are people of all ages, occupations and genders. Therefore convenience sampling technique is used for current study. Students from Riphah International University, Islamic International University and SZABIST University, Islamabad are included coming from very diverse areas, backgrounds, occupations and age. For participants a unique identification code is used at time 1 , to be able to reach the same respondents at time 2 . The survey is self-administered. At time 1, the questionnaires for measuring participants' identification with Pakistani cricket team and trust after negative incident are filled by the respondents. At time 2, after reading the scenario (about the negative incident and media portrayal of that incident), same participants' are requested to fill the questionnaire of content informativeness, content credibility and source credibility (media influence). To prove the study hypotheses, half of the respondents are presented with the scenario of a TV cricket talk show in favor of the accused party and the other half against the accused party.

Before measuring the moderating role of media influence, the respondents will first be told an assumed scenario of negative incident related to performance/integrity of a player from the Pakistan national cricket team, broadcasted on cricket talk show on GEO Sports (an official broadcaster of International cricket matches in Pakistan). They are asked to assume a player of the team involved in a negative incident. After that they are asked to assume a TV cricket talk show in sports media discussing the negative incident of a player. Half of the respondents are told a scenario discussing the incident in a favorable tone to accused party. While the other half are told a scenario in which the tone of the TV cricket talk show are against the accused party. Further they are also told to assume the message to have content informativeness, content credibility and being presented by a credible source (Imran Khan).

The moderation effect is examined for scenarios when cricket talk show is talking against and in favor of the accused players and perceived content credibility and informativeness and perceived source credibility of respondents is present. To measure team identification and trust after negative incident, scales by Wann and Branscomb (1993) and DelgadoBallester (2004) respectively are used. To tap media influence, source credibility instrument by Ohanian (1990), content credibility instrument by MacKenzie and Lutz, 1989), and content informativeness scale by Ducoffe (1995) of message presented by media are measured.

\section{Analysis and Results}


Bivariate correlation is tested to assess the strength of relationship between the variables and regression analysis is to test the hypothesis with the help of SPSS 17.0. The Cronbach Alpha reliabilities of all the scales used in the study are above the recommended level of 0.7 (Hair et al., 2006) as shown diagonally in Table 2. Total sample size is 399 with 272 male and 127 female subjects. The number of married and unmarried respondents is 103 and 296 respectively. Age varies from 11 to above 50 and qualification from Matriculation to M.Phil. Among respondents, 232 are students and rest belongs to different occupations such as, teachers, army personnel, businessmen and doctors. Correlation among all variables is significant at 0.01 levels (Table 2) such as Team Identification is positively associated with trust after negative incident $(r=0.744, p$ $<0.01)$. Correlation matrix provides a provisional support to hypothesis.

Table 2: Mean, Standard Deviation, Correlation and Reliabilities

\begin{tabular}{lllllllll}
\hline & Variables & Mean & S.D. & $\mathbf{1}$ & $\mathbf{2}$ & $\mathbf{3}$ & $\mathbf{4}$ & $\mathbf{5}$ \\
\hline $\mathbf{1}$ & $\begin{array}{l}\text { Team Identification } \\
\text { Trust After Negative }\end{array}$ & 3.3 & 0.77 & $(0.8)$ & & & & \\
$\mathbf{2}$ & Incident & & & & & & \\
$\mathbf{3}$ & Content Informativenes & 3.3 & 0.98 & $0.695^{* *}$ & $(0.9)$ & & & \\
$\mathbf{4}$ & Content Credibility & 3.4 & 0.93 & $0.281^{* *}$ & $0.189^{* *}$ & $(0.9)$ & & \\
$\mathbf{5}$ & source credibility & 3.4 & 0.75 & $0.417^{* *}$ & $0.488^{* *}$ & $0.528^{* *}$ & $(0.8)$ & \\
\hline
\end{tabular}

$\mathrm{N}=196, * * \mathrm{p}<0.01$, Correlation is significant at the 0.01 level (2-tailed)

Simple regression is performed to test the $\mathrm{H}_{1}$, while multiple regression to test hypothesis $\mathrm{H}_{2 \mathrm{a}}, \mathrm{H}_{2 \mathrm{~b}}, \mathrm{H}_{2 \mathrm{c}} \& \mathrm{H}_{3 \mathrm{a}}, \mathrm{H}_{3 \mathrm{~b}}$, and $\mathrm{H}_{3 \mathrm{c}}$. Table 3 shows the linear regression. In step one and two, the control variables are entered followed by entering the independent variable at step 3. Table 4 shows multiple regression $(\mathrm{N}=203)$. In step one and two, control variables are entered while in step three, independent variable. In step 4, first interaction term and independent variable are entered. The same steps are repeated for second and third interaction term. The test result support the $\mathbf{H}_{\mathbf{1}}$ as shown in Table 3 ( $\beta=0.74, \mathrm{p}<$ $0.001)$.

Table 3: Simple Regression

\begin{tabular}{|c|c|c|}
\hline \multirow{2}{*}{\multicolumn{3}{|c|}{$\begin{array}{l}\text { Predictor } \\
\text { Step } 1\end{array}$}} \\
\hline & & \\
\hline Control Variable (age) & & 0.15 \\
\hline \multicolumn{3}{|l|}{ Step 2} \\
\hline $\begin{array}{l}\text { Control } \\
\text { (occupation) }\end{array}$ & & 0.17 \\
\hline \multicolumn{3}{|l|}{ Step 3} \\
\hline Team Identification & $0.740 * * *$ & 0.555 \\
\hline
\end{tabular}

Trust After Negative Incident is dependent variable, $* \mathrm{p}<0.05,{ }^{* *} \mathrm{p}<0.01, * * * \mathrm{p}<0.001$ For scenario 1, the result supports the $\mathbf{H}_{2 \mathrm{a}}$ as shown in Table $4\left(\beta=0.254^{* *}, \mathrm{p}<0.01\right)$ and $\mathbf{H}_{2 \mathbf{b}}$ as shown in Table 4 ( $\beta=0.285^{* *}, \mathrm{p}<0.01$ ). The result supported $\mathbf{H}_{2 \mathrm{c}}$ as $\beta=$ $0.517 * * *$ at $\mathrm{p}<0.001$ according to Table 4 . 
Table 4: Multiple Regressions for Scenario 1

\begin{tabular}{llll}
\hline Predictor & $\beta$ & $\mathbf{R 2}$ & $\Delta \mathbf{R 2}$ \\
\hline Step 1 & & & \\
Control Variables & & 0.064 & \\
Step 2 & & & \\
& $0.761^{* *}$ & & \\
Independent Variable & $*$ & 0.623 & \\
Step 3 & & & \\
& $0.538^{* *}$ & & \\
Independent Variable & $*$ & & \\
Interaction 1 & $0.254^{* *}$ & $0.64^{* *}$ & $0.013^{* *}$ \\
Step 4 & $0.509^{* *}$ & & \\
& $*$ & & \\
Independent Variable & $*$ & & \\
Interaction 2 & $0.285^{* *}$ & $0.64^{* *}$ & $0.016^{* *}$ \\
Step 5 & & & \\
Independent Variable & $0.284^{*}$ & & \\
& $0.517^{* *}$ & & $0.66^{* * *}$ \\
Interaction 3 & $*$ & $0.032^{* * *}$ \\
\hline
\end{tabular}

Trust After Negative Incident is dependent \& age and occupation control variable, $* \mathrm{p}<0.05, * * \mathrm{p}<0.01, * * * \mathrm{p}<0.001$

Variance explained by moderator 1 is only 0.013 . Overall model fit is good with beta value of moderation as 0.0254 with $\mathrm{R}^{2} 64 \%$. Variance explain by moderator 2 is only 0.016 . Overall model fit is good with beta value of moderation as 0.285 with $\mathrm{R}^{2}$ $64 \%$. Variance explained by moderator 3 is only 0.032 . Overall model fit is good with beta values of 0.517 and $\mathrm{R}^{2} 66 \%$.

Table 5: Multiple Regressions for Scenario 2

\begin{tabular}{llll}
\hline Predictor & $\boldsymbol{\beta}$ & $\mathbf{R 2}$ & $\Delta \mathbf{R 2}$ \\
\hline Step 1 & & & \\
Control Variable & & 0.001 & \\
Step 2 & & & \\
Independent Variable & $0.709 * * *$ & 0.491 & \\
Step 3 & & & \\
Independent Variable & $0.730^{* * *}$ & & \\
& -0.028 & & \\
Interaction 1 & $(\mathrm{ns})$ & 0.491 & \\
Step 4 & & & \\
Independent Variable & $0.386^{* * *}$ & & \\
Interaction 2 & $0.400^{* * *}$ & $0.540^{* * * *}$ & $0.049 * * *$ \\
Step 5 & & & \\
Independent Variable & $0.291 * *$ & & \\
Noor, Qayyum \& Rehman & & \multicolumn{2}{c}{153}
\end{tabular}


Trust After Negative Incident is dependent while occupation is control variable, $* \mathrm{p}<0.05, * * \mathrm{p}<0.01, * * * \mathrm{p}<0.001$, (ns) not significant

For scenario 2, statistical results does not support $\mathbf{H}_{3 \mathrm{a}}$ with reference to Table 5 ( $\beta=$ $0.028 \mathrm{~ns}$ ) when content informativeness is present. $\mathbf{H}_{\mathbf{3 b}}$ is also not supported because content credibility is making the relationship strong $\left(\beta=0.400^{* * *}, \mathrm{p}<0.001\right)$. Moreover, $\mathbf{H}_{\mathbf{3 c}}$ does not stand valid because source credibility is making the relationship strong, with reference to Table $5(\beta=0.479 * * *, p<0.001)$.

Variance explain by moderator 2 is only 0.049 . Overall model fit is good with beta value of moderation as 0.400 and $\mathrm{R}^{2}$ as $54 \%$. Variance explained by moderator 3 is only 0.048 . Overall model fit is good with beta values of 0.479 and $\mathrm{R}^{2}$ as $54 \%$.

\section{Discussion and Conclusion}

The overall goal of this research is to gain insight on fans' trust on cricket team after the involvement of a player in a negative incident. A model is developed in the sports context with an antecedent of team identification and trust after negative incident as an outcome. Media impact through content informativeness, content credibility and source credibility is used as a moderator. Total of 7 hypotheses are formulated based on literature and 4 are supported. The main hypothesis of team identification and trust after negative incident is supported by the results. In addition, content informativeness, content credibility and source credibility have proved to be potential moderators on the relationship of team identification and trust after negative incident regardless media is portraying negative or positive image of players. People if love a players will continue to like even after image being negatively portrayed by media.

Pakistanis are cricket crazy nation. They identify themselves with the cricket team. Cricket occupy important place in their lives. History of Pakistan cricket shows many incidents in which cricket players are involved in performance or integrity related incidents. But for Pakistani loyal fans, these are the minor issues which cannot decrease the level of trust and loyalty towards cricket team. They show the factor of group favoritism for their cricket team. It can be concluded that content informativeness and content credibility being an important attributes of a message may bring attitude change. It is the responsibility of media to provide public with relevant, timely and true information. In the sports context, especially if someone is being falsely accused and is innocent, the sports media should bring it to public so that fans can maintain level of trust on the player or team.

As it is obvious from the results that fans don't really trust the credible message even delivered through a credible source when it is against their self-esteem and positive distinctiveness. Although the message provided to fans through sport media (TV cricket talk shows) is true but is against the accused party, the already developed level of trust and image with their in group members (cricket team) has not led them to trust the message. Possible conclusion from this result may be that sports media should avoid to have detailed discussions of the negative incidents of the sports players, especially if the accused party is really guilty. It can be a reason to hurt many fans. The particular news must have reached to fans through other news channels. The role of sports media is accurate reporting of the negative incident and the degree of attention the incident 
receives is critical. Discussion against the accused party in the TV talk shows may reduce the ranking of the sports channel telecasting that show in the eyes of fans.

Sports fans represent a large portion of any country's population. If the news is against the positive self-image of the fans, a particular channel or talk show may lose viewership and ultimate loss of revenues. It can definitely indirectly affect the sponsor of that show or channel in the form of reduced sales. As a result, the particular sports channel may lose many of its good revenue generating sponsors. Therefore, sports channels must be very careful regarding how much they can highlight or refrain from broadcasting the negative aspects of the incident for sports fans.

\subsection{Managerial Implications}

Cricket generates a large audience, and therefore offers sports media a large amount of exposure to large audience. This study has implications for authorities of sports media, as it will demonstrate the impact of their portrayal the negative incidents. Unverified or exaggerated comments by reporters on sports media may deteriorate the publics' perceptions of source credibility and credibility and informativness of the content presented by the sports media.

\subsection{Limitations}

The present study is restricted only up to three variables, i.e. team identification, media influence (to be tapped by measuring the credibility and informativeness of the content and source credibility of the message presented by TV cricket talk shows) and fans' trust after negative incident. Therefore it may have missed some other significant antecedents and consequents of the variables considered in this study. The sample only includes respondents from the area of Rawalpindi and Islamabad, therefore, the results of the study cannot be generalized for whole country.

\section{References}

AFP. (2006). Retrieved on May 2, 2014, from http://cricketarchive.com/Archive/Articles/5/5301.html

Ajzen, I. (1991). The Theory of Planned Behavior. Organizational Behavior and Human Decision Process, 50, 179-211.

Ashforth, B. E., \& Mael, F. (1989). Social identity theory and the organization. Academy of Management Review, 14, 20-39.

Anderson, J.C., \& Narus, J.A. (1990). A model of distributor firm and manufacturer firm working partnership. Journal of Marketing, 54, 42-58.

Bruce, T., \& Tini, T. (2008). Unique crisis response strategies in sports public relations: Rugby league and the case for diversion. Public Relations Review, 34, 108-115.

Bracket, L.L., \& Carr, B.N. (2001). Cyberspace advertising vs. other media: consumer vs. mature student attitude. Journal of Advertising Research, 41(5), 23-32.

Beech, J., \& Chadwick, S. (2006). Beech, John; Chadwick, Simon, eds. The marketing of Sport. Prentice Hall and Financial Times. p. 592. ISBN 978-0-273-68826-6.

Delgado-Ballester, E., \& Munuera-Alemán, J. (2001). Brand trust in the context of consumer loyalty. European Journal of Marketing, 35, 1238-1258.

Delgado-Ballester, E., Munuera-Aleman, J. L., Yague-Guillen, M. J. (2003). Development and validation of a brand trust scale. International Journal of Market Research, 45, 35-54. 
Dietz-Uhler, B., End, C, Demakakos, N., Dickirson, A., \& Crantz, A. (2002). Fans' reaction to law-breaking athletes. International Sports Journal, 6, 160-170.

Ducoffe, R. H. (1996). Advertising value and advertising on the web. Journal of Advertising Research, 36(5), 21-35.

Eisend, M. (2006). Source credibility dimensions in marketing communication-a generalized solution. Journal of Empirical Generalizations in Marketing, 10(2), 1-33.

Fink, J., Parker, H., Brett, M., \& Higgins, J. (2009). Off-field behavior of athletes and team identification: Using social identity theory and balance theory to explain fan reactions. Journal of Sport Management, 23, 142-155.

Gwinner, K., \& Swanson, S. R. (2003). A model of fan identification: Antecedents and sponsorship outcomes. Journal of Services Marketing, 17, 275-294.

Goldsmith, R. E., B. A. Lafferty., \& Newell, S. J. (2000). The impact of corporate credibility and celebrity credibility on consumer reaction to advertisements and brands. Journal of Advertising, 29(3), 43-54.

Grewal, D., Gotlieb, J., \& Marmorsein, H. (1994). The moderating effects of message framing and source credibility on price perceived risk relationship. Journal of Consumer Research, 21, 144-153.

Hewstone, M., Rubin, M., \& Willis, H. (2002). Intergroup bias. Annual Review of Psychology, 53, 575-604.

Hair, J. F., Black, W. C., Babin, B. J., and Anderson, R. E. (2006). Multivariate Data analysis. $7^{\text {th }}$ edition.

Hovland, C. I., Janis, I. L., \& Kelley, H. H. (1953). Communication and Persuasion: Psychological Studies of Opinion Change. New Haven: Yale University Press. Print 8. Janssen, O., \& Huang, X. (2008). Us and me: Team identification and individual differentiation as complementary drivers of team members' citizenship and creative behaviors. Journal of Management, 34(1), 69-88.

Keh, H. T., Xie, Y. (2009). Corporate reputation and customer behavioral intentions: the roles of trust, identification and commitment. Industrial Marketing Management, 38, 732-742.

Koo, K.,Y. \& Xiang (2012). Generation Y consumers' value perceptions toward apparel mobile advertising: Functions of modality and culture. International Journal of Marketing Studies, 4(2).

Kramer, R. M., Brewer, M. B., Hanna, B. A. (1996). Collective trust and collective action: the decision to trust as a social decision. In R. M. Kramer, T. R. Tyler (Ed.), Trust in Organizations: Frontiers of Theory and Research (pp. 357-389). Thousand Oaks, CA: Sage Publications.

Kwak, H., Zinkhan, G. M., \& DeLorme, D. E. (2002). Effects of compulsive buying tendencies on attitude towards advertising: the moderating role of exposure to TV commercials and TV shows. Journal of current Issue and Research in Advertising, 24(2), 17-32.

Kwon, H. H., \& Armstrong, K. L. (2002). Factors influencing impulse buying of sport team licensed merchandise. Sport Marketing Quarterly, 11, 151-163.

Kiousis, S. (2001). Public trust or mistrust? Perceptions of media credibility in the information age. Mass Communication \& Society, 4(4), 381-403. 
Kaasinen, E. (2003). User needs for location-aware mobile services. Personal and Ubiquitous Computing, 7, 70-79.

Lafferty, B. A., Goldsmith, R. E., \& Newell, S. J. (2002). The dual credibility model: The influence of corporate and endorser credibility on attitudes and purchase intentions. Journal of Marketing Theory and Practice., 10(3), 1-12.

Lee, C., Bang, H., Lee, D. (2013). Regaining fans' trust after negative incidents: Fit between responses and nature of incidents. Sport Marketing Quarterly, 22, 235-245.

Lee, J., \& Ferreira, M. (2011). Cause-related marketing: The role of team identification in consumer choice of team licensed products. Sport Marketing Quarterly, 20, 157-169.

Luo,C., Luo, X., Schatzberg, L., Sia, C.L. (2013). Impact of informational factors on online recommendation credibility: the moderating role of source credibility. Decision Support System, 56, 92-102.

MacKenzie, S. B., \& Lutz, R. L. (1989). An empirical examination of the structural antecedents of attitude toward the ad in an advertising pretesting context. Journal of Marketing, 53, 48 - 65.

Mullin, B., Hardy, S., \& Sutton, W. (2000). Sports Marketing. Champaign, IL: Human Kinetics.

Madrigal, R., \& Dalakas, V. (2008). Consumer psychology of sport: More than just a game. In G.P. Haugtvedt, P.M. Herr, and F.R. Kardes (Eds.), Handbook of Consumer Psychology (pp. 857-876). New York, NY: Taylor \& Francis Group, LLG.

Mattila, A. S. (2001). The impact of relationship type on consumer loyalty in a context of service failures. Journal of Service Research, 4, 91-101.

Matzler, K., Pichler, E., Fuller, J. \& Mooradian, T.A. (2011). Personality, person-brand fit and brand community: an investigation of individuals, brands and brand communities. Journal of Marketing Management, 27(9-10), 874-890.

Mike Rice fired by Rutgers. (2013). Retrieved from http://www.cbsnews.com/news/mike-rice-fired-by-rutgers-after-video-shows-coachabusing-players/

Milne, G., \& Gordon, M. E. (1993). Direct Mail Privacy - Efficiency Trade-Offs within an Implied Social Contract Framework. Journal of Public Policy \& Marketing, 12(2), $206-216$.

Moore, J. J., \& Rodgers, S. L. (2005). An examination of advertising credibility and skepticism in five different media using the persuasion knowledge model. American Academy of Advertising. Conference proceeding. 10-18. 9p.

Morgan, R. M., \& Hunt, S. D. (1994). The commitment-trust theory of relationship marketing. Journal of Marketing, 58(3), 20-38.

Moorman, C., Deshpande, R., \& Zaltman, G. (1993). Factors affecting trust in market research relationship. Journal of Marketing, 57, 81-101.

Ohanian, Roobina (1990). Construction and Validation of a Scale to Measure Celebrity Endorsers' Perceived Expertise, Trustworthiness, and Attractiveness. Journal of Advertising, 19(3), 39-52.

Pakistan Cricket Board. (2014). Retrieved on May 5, 2014, from

http://www.pcb.com.pk/about-pcb.html

Pakistan cricket spot-fixing scandal. (2013). Retrieved on May 7, 2014, from

http://en.wikipedia.org/wiki/Pakistan_cricket_spot-fixing_scandal 
Potter, W. J. (2011). Conceptualizing mass media effect. Journal of Communication, 61, $896-915$.

Ravald, A., \& Gronroos, C. (1996). The value concept and relationship marketing. European Journal of Marketing, 30, 19-30.

Rotzoll, K.B., Haefner, J.E., \& Sandage, C.H. (1990). Advertising in Contemporary Society: Perspectives Toward Understanding. $2^{\text {nd }}$ Edition. South-Western: Cincinnati, $\mathrm{OH}$.

Soh, H., Reid, L. N., \& King, K. W. (2007). Trust in different advertising media. Journalism \& Mass Communication Quarterly, 84(3), 455-476.

Siau, K., \& Shen, Z. (2003). Building Customer Trust in Mobile Commerce. Communications of the ACM, 46(4), 91 - 94.

Sudarsan, S. (2012). Retrieved on May 2, 2014, from http://www.huffingtonpost.com/sudio-sudarsan/india-cricket-branding-csk-

_b_1560870.html

Tajfel, H., \& Turner, J. C. (1979). An Integrative Theory of Intergroup Conflict. In W.G. Austin \& S. Worchel (Eds.), The social psychology of intergroup relations (pp.33-47). Monterey, CA: Brooks/Cole.

Tajfel, H., Turner, J. C. (1985). The social identity theory of intergroup behaviour. In S. Worchel, W.G. Austin (Eds.), Psychology of Intergroup Relations (pp. 7-24) NelsonHall.

Verma, I. (2014). Advertising credibility: a review of literature. International Interdisciplinary Research Journal, 2(1), 188-199.

Wann, D. L., \& Branscomb, N. R. (1993). Sports fans: Measuring degree of identification with their team. International Journal of Sport Psychology, 24, 1-17.

Wann, D. L., Dolan, T. J., McGeorge, K. K., \& Allison, J. A. (1994). Relationship between spectator identification and spectators' perceptions of influence, spectators' emotions and competition outcome. Journal of Sport and Exercise Psychology, 16, 347364.

Wann, D. L., \& Polk, J. (2007). The positive relationship between sport team identification and belief in the trustworthiness of others. North American Journal of Psychology, 9(2), $251-256$.

Wann, D. L., Tucker, K. B., \& Schrader, M. P. (1996). An exploratory examination of the factors influencing the origination, continuation, and cessation of identification with sport teams. Perceptual and Motor Skills, 82, 995-1001.

Wilson, B., Stavros, G., \& Westberg, K. (2008). Player transgressions and the management of the sport sponsorship relationship. Public Relations Review, 34, 99-107.

Wann, D.L., Koch, K., Knoth, T., Fox, D., Aljubaily, H. and Lantz, C.D. (2006). The impact of team identification on biased predictions of player performance. The Psychological Record, 56, 55-66.

West, M.D. (1994). Validating a Scale for the Measurement of Credibility: A Covariance Structure Modeling Approach. Journalism Quarterly 71 (1), 159-168.

Yannopoulou, N., Koronis, E., \& Elliott, R. (2011). Media amplification of brand crisis and its affect on brand trust. Journal of Marketing Management, 27, (5-6), 530-546. 
Zhu, J. J. H., \& He, Z. (2002). Information accessibility, user sophistication and source credibility: the impact of the internet on value orientations in Mainland China. Journal of Computer-Mediated Communication, 7(2). doi:10.1111/j.1083-6101.2002.tb00138.x 